АКТУАЛЬНІ НЕСТАНДАРТНІ ФОРМИ ЗАЙНЯТОСТІ УКРАЇНЦІВ У НОВИХ РЕАЛІЯХ СУЧАСНОСТІ

\title{
CURRENT NON-STANDARD FORMS OF EMPLOYMENT OF UKRAINIANS IN THE NEW REALITIES OF MODERNITY
}

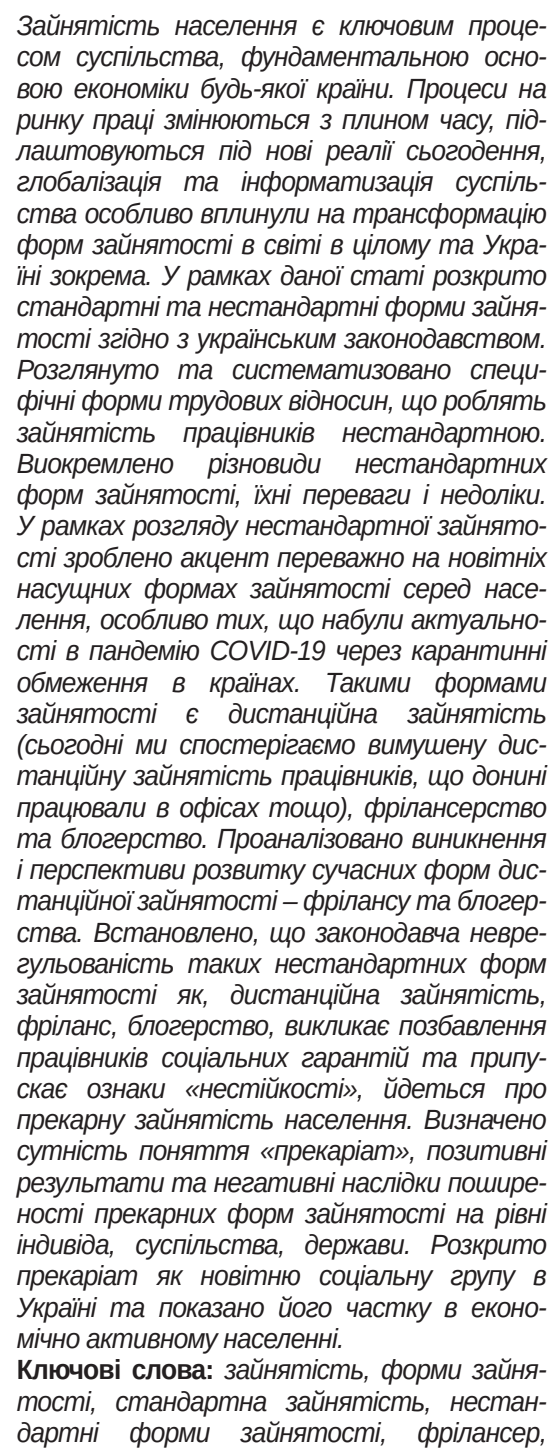

блогерство, дистаниійна зайнятість, прекаріат

Employment is a key process of society, the fundamental basis of the economy of any country. Processes in the labor market change over time, adapt to the newrealities of today, globalization and informatization of society have particularly affected the transformation of forms of employment in the world in general and in Ukraine in particular. Within the framework of this article, standard and non-standard forms of employment according to Ukrainian legislation are disclosed. The specific forms of labor relations that make employment of non-standard employees are considered and systematized. Varieties of non-standard forms of employment, their advantages and disadvantages are singled out. As part of the consideration of non-standard employment, the emphasis is mainly on the latest urgent forms of employment among the population, especially those that have become relevant in the COVID-19 pandemic due to quarantine restrictions in countries. Such forms of employment are remote employment (today we see forced remote employment of employees who have worked in offices until now, etc.), freelance and blogging. The origin and prospects of development of modern forms of remote employment - freelance and blogging are analyzed. It has been established that the legislative unregulation of such non-standard forms of employment as remote employment, freelance, blogging causes deprivation of employees of social guarantees and suggests signs of "instability", it is a question of precarious employment. The essence of the concept of "precariat", positive results and negative consequences of the prevalence of precarious forms of employment at the level of the individual, society, state are determined. Precariat as the newest social group in Ukraine is revealed and its share in the economically active population is shown.

Key words: employment, forms of employment, standard employment, non-standard forms of employment, freelancer, blogging, remote employment, precariat.
Постановка проблеми. Зайнятість населення $є$ індикатором стабільності та благополуччя українців. Ринок праці $є$ соціальним інститутом, що змінюється, підлаштовується під реалії часу. В Україні, як і в багатьох країн світу, відбувається суттєва трансформація зайнятості, її основних форм та видів. У зв'язку з розвитком технологій відбуваються зміни у сфері працевлаштування, поряд із стандартними формами зайнятості, 3'являються альтернативні, модерні. Цей аспект має як позитивні сторони, так і негативні. 3 одного боку, нестандартні форми зайнятості володіють більшою гнучкістю, що необхідно в умовах глобалізації та криз, які відбуваються в суспільстві. 3 іншого боку - породжує ризик бідності серед населення та зріст такого класу, як прекаріат.

Проте надомна праця, що стала можливою з розвитку інформаційних технологій, у зв'язку зі змінами, що відбулися у 2020 році у всьому світі, набула нагальності. Роботодавці почали шукати шляхи збереження свого бізнесу та штату співробітників й набули розповсюдження нестандартні форми зайнятості, зокрема дистанційна зайнятість. Цифрові платформи надали можливість зв'язувати роботодавців та співробітників. Інші, залишившись без основного місця роботи, знайшли реалізацію, завдяки всесвітній мережі інтернет, в різних соціальних мережах тощо. 
На сьогодні, в умовах карантинних обмежень по всьому світі, у зв'язку з пандемією, зміни, що відбуваються у сфері зайнятості, викликають науковий інтерес та потребують вивчення.

Питанням дослідження різних аспектів нестандартної зайнятості присвячені роботи відомих зарубіжних та українських учених М. Койне, Г. Роджерса, Г. Стэндінга, Д. Такера, В. Бобкова, П. Бізюкава, А. Колота, Е. Лібанової, О. Грішнової та інших. Прекаріату присвячені праці Г. Стендінга, Ж. Тощенко тощо.

Метою роботи $\epsilon$ розгляд актуальних нестандартних форм зайнятості, які набули поширення в Україні в умовах карантинних обмежень у зв'язку з пандемією.

Виклад основного матеріалу. Зайнятість - діяльність, що не суперечить законодавству, а також приносить громадянам задоволення їхніх потреб, за яку вони отримують заробіток. До основних форм зайнятості згідно з українським законодавством відносяться: повна й неповна (часткова) зайнятість, явна та прихована, первинна та вторинна, гнучкі форми зайнятості [1].

За характером організації робочих місць та робочого часу розрізняють: стандартну зайнятість та нестандартну зайнятість. «Стандартною» зазвичай вважається зайнятість із найму в режимі повного робочого дня на основі безстрокового трудового договору на підприємстві або в організації, під безпосереднім керівництвом працедавця або призначених ним менеджерів. А всі форми зайнятості, що відхиляються від описаного стандарту, включаючи самозайнятість, можуть розглядатися як «нестандартні» [2]. Нестандартна форма зайнятості - це зайнятість, яка не має певних стандартів і повної регламентації робочого часу, наприклад, тимчасова, запозичена зайнятість, самозайнятість громадян, дистанційна зайнятість тощо. В умовах формування постіндустріальної моделі зайнятості виникає безліч нових форм праці.

На сьогодні в науковому дискурсі поряд із поняттям «нестандартна зайнятість» використовують також «нестабільна зайнятість», «атипова зайнятість», «Гнучка зайнятість», «інноваційна зайнятість», тобто всі ті види зайнятості, що не відповідають стандартній зайнятості та поняттю стандарт. Хоча «стандарт» - поняття вкрай нечітке та в різний час та різних країнах може відрізнятися.

До нестандартних форм зайнятості належать такі: повна зайнятість за умов гнучких форм організації робочого часу; неповна зайнятість, тобто режим зайнятості - неповний робочий час; тимчасові працівники; зайняті на засадах вторинної зайнятості; зайнятість на основі договорів цивільно-правового характеру; надомна праця; праця за викликом; дистанційна зайня- тість; позикова праця (лізінг персоналу, аутстафінг персоналу, аутсорсинг персоналу); неформальна зайнятість; нереєстрована зайнятість у неформальному секторі [3].

Американський соціолог А. Каллеберг зазначає, що стандартна організація ієрархічних трудових відносин, скоріше, є історичною аномалією, що виникла в XIX ст. як наслідок активної індустріалізації, тоді як різноманітні форми нестандартної зайнятості є загальним правилом. Часта зміна роботи перетворюється в норму, а тривала і гарантована зайнятість у одного роботодавця зустрічається рідше [4].

В умовах інформатизації суспільства ці форми зайнятості все більше замінюють традиційні для індустріального типу суспільства форми, а в умовах сьогодення стали найбільш актуальними. Саме нестандартні форми зайнятості набули поширення та усталеності під час дії карантинних обмежень 2020-21 років, на них зосередимо увагу, на найпопулярніших, виходячи з мети нашого дослідження або на інноваційних формах.

За експертними оцінками, в межах дослідження «Оцінка попиту на професії, які затребувані на ринку праці» Київського міжнародного інституту соціології (KMIC) до переліку затребуваних на ринку праці спеціальностей належать ті, які надають можливість працювати віддалено. Насамперед, це стосується роботи у сфері IT, інтернет-комерції та інтернет-маркетингу, а також кол-центри. Експерти відзначають, що традиційні офісні спеціальності також починають переводити на аутсорс або фріланс своїх працівників, зокрема бухгалтерів, юристів і секретарів. Завдяки Skype нові перспективи розвитку отримують перекладачі, репетитори, психологи та нішеві спеціальності [5].

Розповсюдження нових інформаційних і телекомунікаційних технологій сприяє розвиткові дистанційної роботи. Дистанційна зайнятість - це робота, яка в результаті використання інформаційних та комунікаційних технологій віддаляється від приміщень роботодавця (принаймні, у відношенні не менше $20 \%$ робочого часу). Сутність дистанційної зайнятості працівників полягає в тому, що всі умови, необхідні для якісного виконання особою своїх трудових обов'язків, створені поза межами офісу, що не прив'язує працівника до обов'язкового відвідування офісу. Ці умови можуть бути створені вдома або в іншому місці [6].

Вперше дистанційна зайнятість з'явилась в США, в 1972 році професор Дж.Ніллес ввів термін «телеком'ютінг». На сьогодні українське законодавство не регулює дистанційну зайнятість, хоча є країни, де ця форма закріплена на законодавчому рівні, наприклад, в Греції.

Особливостями дистанційної зайнятості (телероботи) є: взаємодія між працівником 
і роботодавцем у віртуальному середовищі з використанням сучасних інформаційних і комунікаційних технологій; відсутність стаціонарного робочого місця (робота через інформаційні мережі, вдома і в спеціальних центрах, просторово віддалених від офісу чи виробничих приміщень); ненормований робочий час, самостійність методів організації праці та ін. [7].

Вона стала необхідною в умовах кризи, що склалася та завдяки інтернет-технологіям дозволила багатьом підприємствам не збанкрутіти. Слід зазначити, що протягом останнього десятиліття дистанційна робота стала більш поширеною. За оцінками МОП, до пандемії COVID-19 лише 8\% світової робочої сили, або приблизно 260 млн осіб, постійно працювали вдома. Для країн ЄС у 2019 р. частка дистанційних робітників у віці 15-64 років становила лише трохи більше 5\% і залишалася такою протягом останнього десятиліття. А в США за останні 10 років кількість співробітників, які регулярно працюють з дому, виросла на 115\% і досягло 2,8\% всіх працевлаштованих американців (3,9 млн чоловік) [8]. За даними дослідження Соціологічної групи «Рейтинг», станом на березень 29\% дорослого населення України працювали дистанційно [9]. Наприклад, міжнародна компанія «Danon» в Україні, що є прикладом великого бізнесу, від початку пандемії й сьогодні тримає своїх основних працівників на дистанційній або змішаній роботі. До того ж, згідно з дослідженням Colliers International, 82\% опитаних офісних співробітників в 25 країнах світу висловили побажання після повного скасування карантинних заходів продовжувати працювати з дому один або два дні на тиждень [8].

В Україні, за даними платформи HeadHunter, за перші місяці осені найбільші темпи зростання за кількістю вакансій мав «домашній персонал», тобто працівники, які працюють дистанційно, - ріст 363\% [10].

Фріланс як гнучка форма зайнятості - це новий тип зайнятості, який пов'язаний з виконанням ряду завдань без заключення трудового договору з керівництвом. Це новий тип віддаленої дистанційної роботи в умовах розвитку інформаційних технологій. Перевагою $€$ гнучка зайнятість, таких працівників також називають позаштатними. Фрілансер - це зростаюча робоча сила, яка використовує нові технології для виконання робіт, висококваліфікована та професійна [11].

Проте в пандемію короновірусу, коли роботодавці намагалися підтримувати свій бізнес, акцент робився на постійних працівників, а фрілансери не користувалися попитом серед підприємців. Наведемо деякі дані дослідження проведеного Payoneer [12]. Коли почалася пандемія, 32 відсотки фрілансерів відзначили, що попит на їхні послуги впав, при цьому 53\% вва- жали це тимчасовим явищем. Що стосується України, то за результатами цього дослідження, 50\% фрілансерів говорять, що попит на них не знизився з боку європейських клієнтів, проте доходи дещо знизилися (на 4\% у квітні-травні), а зросли трохи (на 3\%) у червні [12].

До гнучких інноваційних форм зайнятості сьогодні ми можемо віднести блогерство. Блогерство є формою зайнятості, оскільки людина має можливість заробляти гроші, і при цьому сама діяльність від ведення блогу може бути єдиним джерелом доходу. Разом із тим блогерство складно однозначно кваліфікувати. Блогерів частково можна віднести до фрілансерів, оскільки вони надають послуги малому, середньому та великому бізнесу.

Це професія, що здобула широкого розповсюдження 3 розвитком «Instagram» як найпопулярнішої соціальної мережі та «YouTube». Інстаграм починає свій розвиток з жовтня 2010 року, у цей день він налічував 25000 користувачів зі всього світу [14], а число користувачів у 2020 року досягло позначки в 1200000000 користувачів [13]. 3 впровадженням карантинних обмежень українці стали більше часу проводити в мережі інтернет: від досугу до роботи.

В «YouTube» блогери монетизують свій канал за рахунок продажу прямої реклами і стандартної монетизації даної платформи, тобто під час трансляції відео «вискакує» реклама якого-небудь виробника, за перегляд якої блогер отримує гроші. Також блогери «YouTube» збільшують свої статки за рахунок кількості переглядів відеоролика. Так, за 1000 переглядів блогер може отримати від 2 до 5 доларів [16].

Відповідно до дослідження в середньому типовий користувач інтернету проводить в он-лайні майже 7 годин надень, з яких близько 2,5 годин йде на використання соціальних мереж. Якщо скласти усе разом, то сумарно всі онлайн-користувачі витрачають більш ніж 10 мільярдів годин на соціальні мережі. Якщо говорити про конкретні платформи, то найбільше зростання в період з липня по вересень показала платформа Instagram - плюс 76 мільйонів користувачів (близько 7\%). До Facebook додалося 45 млн, а до не вельми популярного в Україні Snapchat - 36 млн (не в останню чергу завдяки забороні TikTok в Індії) [15].

Блог є поняттям, що 3'явилося відносно недавно, з розвитком Інтернету. Блог - це веб-сайт, основний вміст якого - регулярно додаються людиною записи, що містять текст, зображення або мультимедіа. Вважається, що перший блог виник в 1992 році - це була сторінка Тіма Бернерс-Лі, на якій він розміщував і публікував в Мережі цікаві новини. Однак форму, до якої ми сьогодні звикли, блоги знайшли тільки в 1996 році. Саме слово «блог» 
утворено з англійських слів «web log», що означають записи в мережевому журналі. Сьогодні воно означає особистий або комерційний сайт певної форми, зміст якого складається з періодично додаються записів, зображень, звукових або відеофайлів [17]. Сьогодні блогерство стало «модною» новітньою професією, яка приносить досить непоганий заробіток, хоча має свої нюанси та не всім підходить.

3 пандемією це для багатьох стало хорошим заробітком, люди проводячи більше часу в мережі інтернет спостерігають за життям блогерів з різних частин світу та спостерігають за змінами з їх житті, в житті їх країн, за змінами які спричинив ковід. Блогери мають й негативний вплив на аудиторію, вони нав'язують рекламні бренди, спосіб життя тощо, тобто відбувається маніпуляція суспільною свідомістю.

Блогерів називають лідерами натовпу, причому як в позитивному, так і в негативному ключі. Але, кажучи більш точно, вони $є$ лідерами публіки, оскільки, згідно Габріелю Тард, публіку від натовпу відрізняє взаємодія людей на відстані. Позитивним моментом лідерства $€$ те, що блогери часто закликають своїх передплатників надавати допомогу благодійним фондам, тваринам, надавати адресну допомогу. А негативним моментом може послужити, наприклад, ситуація, коли блогер закликає свою аудиторію вийти на мітинг чи влаштувати страйк. У такому випадку публіка може плавно перерости в натовп, але вже в розумінні Гюстава Лебона [16].

Завдяки соціальним мережам, під час пандемії стало можливо продажу товарів, які раніше продавалися через стаціонарні магазини. Так, створюються групи, виставляється товар та продавець працює на доставку, що не порушує карантинні обмеження. За даними Statista, поточний відсоток рознічних продажів в електронній комерції складає близько 15. Це число зростає з кожним роком, i Statista прогнозує, що воно досягло 17,5\% у 2021 році та $22 \%$ у 2023 році [18].

Саме на основі розповсюдження нестандартних форм зайнятості, з'являється новий соціальний клас - прекаріат. Це відносно новий феном глобалізаційного світу. Г. Стендінг пише так, що більшість з тих, кого називаємо прекаріатом не бачили ні одного разу свого роботодавця, не знають про кількість співробітників в компанії. Люди не мають стабільного заробітку тощо [19, с. 12]. Однією з особливостей прекаріату $\epsilon$ те, що люди живуть сьогоднішнім днем, оскільки тут немає мови про кар'єру або професійне самовдосконалення [19, с. 39].

У структурі прекаріата Тощенко виділяе такі елементи: групи населення: зайняті на неформальній роботі; зайняті на тимчасовій роботі; працюють неповний робочий день або перебиваються сезонними і випадковими (епізодичними) заробітками; зайняті позикових працею; безробітні; частина мігрантів [20]. Особливо автор виділяе ті групи, які знаходяться в прикордонному стані, - фрілансери і молодь, що тільки вступає в трудове життя [21]. Проте це лише випадок, тому що ми бачимо що не всі форми гнучкої зайнятості породжують прекаріат. Сутність прекаріату є двоїстою, адже до прекаріїв одночасно можна віднести найменш конкурентоспроможні групи, що задіяні у некваліфікованій трудовій діяльності (сезонні працівники; зайняті в особистих господарствах, зокрема селянських; безкоштовно працюючі не в особистих господарствах), а також представників креативних та IT-індустрій, самозайняте населення (як офіційно зареєстровані на рівні з приватними підприємцями, так і незареєстровані), що працюють і надають кваліфіковані послуги з огляду на ті професійні сфери, до яких вони залучені. Зокрема, це фотографи, дизайнери, моделі, журналісти, музиканти, веб-розробники, мобільні розробники та програмісти, представники рекламної індустрії (редактори, блогери, стилісти), письменники, психологи, онлайн-консультанти, фахівці з маркетингу (спеціалісти з продажу і підтримки клієнтів, експерти з просування бренду), дослідники соціогумантіраних напрямів тощо. Багато хто з представників даних професій працюють фрілансерами (на відстані від конкретного працедавця, який може перебувати в іншій країні). У такому контексті прекарні форми зайнятості можуть бути усвідомленим вибором тих людей, які змінили свої ціннісні установки, обрали інший стиль життя та роботи, наприклад, дауншифтинг - що є відмовою від кар'єрних домагань, виснажливих професійних домагань для життя у задоволенні, digital-nomads - цифрові кочівники, що працюють он-лайн, подорожуючи світом, тощо [4].

Висновки 3 проведеного дослідження. Отже, зайнятість ідентифікується як нестандартна, якщо вона не заборонена чинним законодавством України, однак за особливістю організації режиму робочого часу, робочого місця і умов праці не відповідає стандартним правилам, що були прийняті при індустріалізації. Нестандартні форми зайнятості можуть вирішити проблему безробіття в країні, особливо пов'язаною 3 пандемією COVID-19. Багато роботодавців змінили стандартну зайнятість в офісі на дистанційну або надомну роботу своїх співробітником. Тобто сьогодні ми маємо справу з вимушеною дистанційною зайнятістю на ринку праці світу. Нагальними формами зайнятості сьогодні $€$ дистанційна зайнятість, фріланс, блогерство. Ці форми мають нестійкий характер та не мають законодавчого врегулювання, що призводить 
до розповсюдження та зростання такого соціального класу серед українців, як прекаріат. Тобто розглянуті форми зайнятості вкрай актуальні сьогодні, проте потребують чіткого визначення в правовому полі.

\section{ЛІТЕРАТУРА:}

1. Закон України «Про зайнятість населення» (Закон від 05.07.2012 № 5067-VI (Редакція станом на 04.03.2021)). URL : https://zakon.rada.gov.ua/ go/5067-17.

2. Гузар У.Е., Луцик М.В. Нестандартные фрормы занятости в условиях развития постиндустриального общества. Соціально-економічні проблеми сучасного періоду України. Проблеми інтеграції України у світовий фрінансовий простір. Вип. 1 (99). URL : http://ird.gov.ua/sep/sep20131(99)/sep20131(99)_467_ HuzarUY,LutsykMV.pdf.

3. Давидюк Л.П. Нестандартні фрорми зайнятості в системі трансорормації міжнародного ринку праці. Економічний аналіз : зб. наук. праць / Тернопільський національний економічний університет; редкол. : В.А. Дерій (голов. ред.) та ін. Тернопіль : «Економічна думка», 2015. Том 20. С. 30-34.

4. Овчиннікова О.В. Прекарні фрорми зайнятості населення: сутність і прояви. Український соціум. 2016. № 1(56). C. 54-64. URL : https://ukr-socium. org.ua/wp-content/uploads/2016/01/54-64_no-1_vol56_2016_UKR.pdf.

5. Дослідження «Оцінка попиту на профресії, які затребувані на ринку праці» підготовлено в межах проекту «Економічне і соціальне відновлення Донбасу». Підготовано Київським міжнародним інститутом соціології на замовлення Програмою Розвитку ООН в Україні за фрінансової підтримки Уряду Японії. URL : http://www.kiis.com.ua/materials/pr/20151230_ PROON/Report_Employment_KIIS_final_ukr.pdf.

6. Іншин М.І. Сутність і значення дистанційної зайнятості працівників в Україні. Науковий Вісник Ужгородського національного університету. 2014. Серія ПРАВО. Випуск 28. Том 2. С. 35-38.

7. Новак І.М. Соціальні інновації на ринку праці: фрлексибілізація та прекаризація зайнятості в Україні. Вісник економічної науки України. 2016. № 1. C. 92-97. URL : http://dspace.nbuv.gov.ua/bitstream/ handle/123456789/106267/14-Novak.pdf?sequence=1.

8. Беззуб І. Дистанційна фрорма зайнятості: українські та зарубіжні реалії. Громадська думка про правотворення. 2020. № 16(201). С. 4-11. URL : http:// nbuviap.gov.ua/images/dumka/2020/16.pdfe
9. Моніторинг суспільної думки. Березень 2020. Соціологічна група «Рейтинг». URL : http://ratinggroup. ua/ru/research/?page=.

10. Шушпанов Д.Г. Інтернет-фріланс в умовах глобальних викликів: мотиваційний аспект. ДВНЗ «Київський національний економічний університет імені Вадима Гетьмана». URL : https://ir.kneu.edu.ua/bitstream/ handle/2010/35219/Sts_11_20_61.pdf?sequence=1.

11. The Freelancer: A Conceptual Review. Vol. 2 No. 3: Special Issue on Entrepreneurship and Business Management. URL : https://sainshumanika.utm.my/ index.php/sainshumanika/article/view/428.

12. Friedman K. Состояние фрриланса во время COVID-19. 2020. Блог Payoneer URL : https://blog. payoneer.com/ru/freelancers-ru-1/industry-tips-fl-ru/ freelancing-during-covid-19-report/.

13. Скільки користувачів в Instagram в 2020 році. Моя довідка - Корисні поради. URL : https://mydovidka.com/ instagram/skilki-koristuvachiv-v-instagram-v-2020-roci.

14. В каком году появился Инстаграм? Хронология важных событий в истории сети. SocialnieSety. ry. URL : https://socialniesety.ru/v_kakom_godu_ poyavilsya_instagram_hronologiya_vazhnyh_ sobytiy_v_istorii_seti.

15. Заікова І. Як пандемія вплинула на використання інтернету? Світ йде в «онлайн». 2020. URL : https://naparise.com/posts/yak-pandemiia-vplynula-navykorystannia-internetu-svit-ide-v-onlain.

16. Архипова В.Ю. Блогерство: социологический аспект. Мир современной науки. Москва, 2020. № 3(61). С. 56-58.

17. Блог (матеріал 3 Вікіпедії). URL : https://ru.wikipedia.org/wiki/Блог.

18. Stevanovic I. eCommerce Statistics \& the Industry's Vibrant Future. 2019. Statistic. URL : https:// kommandotech.com/statistics/ecommerce-statistics.

19. Стэндинг Г. Прекариат: новый опасный класс. Москва : Ад Маргинем Пресс, 2014. 328 с. URL : http://spkurdyumov.ru/uploads/2016/05/prekariatnovyj-opasnyj-klass.pdf.

20. Тощенко Ж.Т. Феномен прекариата: теоретические и методологические основания исследования. Социологические исследования. 2019. No 9. C. 51-63. URL : http://socis.isras.ru/article. $\mathrm{html}$ ?id=7812.

21. Гоць А. Зайнятість і безробіття на українському ринку праці: вплив пандемії COVID-19. Соціальні технології: актуальні проблеми теорії та практики, 2020, Вип. 88. URL : http://soctech-journal. kpu.zp.ua/archive/2020/88/12.pdf. 